\title{
Conventional Identification of Pathogenic Fungi Isolated from Fresh Water Aquarium Fish (O. niloticus and C. gariepinus) Combined with Molecular Identification of Saprolegnia parasitica in Egypt
}

\section{Gamal A. Younis ${ }^{1}$, Abo El Kheir M. EsawY ${ }^{2}$, Rasha M. Elkenany ${ }^{1 *}$, Muhammad M. Shams El DEEN $^{3}$}

${ }^{1}$ Department of Bacteriology, Mycology and Immunology, Faculty of Veterinary Medicine, Mansoura University, Mansoura 35516, Egypt; ${ }^{2}$ Department of Bacteriology, Mycology and Immunology, Animal Health Institute El-Mansoura Branch, Mansoura 35516, Egypt; ${ }^{3}$ Veterinarian, Faculty of Veterinary Medicine, Mansoura University, Mansoura 35516, Egypt.

\begin{abstract}
This study aimed to investigate fungi exist in the skin/fins, gills, and internal organs of two economically essential diseased fresh water fish species with amplification of Internal Transcribed Spacer (ITS1-ITS4) regions of ribosomal DNA as the reference method for Saprolegnia parasitica identification, in Egypt. Among 500 samples from Oreochromis niloticus and Clarias gariepinus, mycological investigations had revealed 148 (29.6\%) fungal isolates with 6 genera: Aspergillus spp. (51.3\%) with A. niger as the most dominant species, Saprolegnia spp (16.2\%), Penicillum spp., Alternaria spp. (10.8\% each), Cladosporium spp. and C. albicans (5.4\%). Moreover, skin/fins (55.4\%) was the most affected area followed by gills (18.9\%) and internal organs (liver $10.8 \%$, kidney $10.2 \%$, eyes $2.7 \%$ and spleen $2 \%$ ). The highest fungal infection rate was demonstrated during autumn (41.7\%), followed by winter season (36\%). The intraperitoneal-challenged $C$. gariepinus groups with $A$. flavus, C. albicans, A. niger and Cladosporium spp. displayed the highest cumulative mortality rate $(100,80,70$ and $70 \%$ respectively), while the intramuscular challenged C. gariepinus groups with $A$. flavus, $A$. niger and $C$. albicans revealed the highest mortality rate (60, 50 and $50 \%$ respectively). Furthermore, presumptive identification of the 24 isolates was initially suggestive of Saprolegnia species. Therefore, PCR assay joined with partial sequencing of ITS gene was confirmed the identification of 9 representative $S$. parasitica strains. This finding confirmed that the diseased fresh water fish species may harbor potential clinically applicable fungal species.
\end{abstract}

Keywords | Aspergillus spp., Clarias gariepinus, Fungi, Oreochromis niloticus, Sparolegnia parasitica.

Received | June 25, 2019; Accepted | August 19, 2019; Published | January 03, 2020

*Correspondence | Rasha M. Elkenany, Department of Bacteriology, Mycology and Immunology, Faculty of Veterinary Medicine, Mansoura University, Mansoura, Egypt; Email: dr_rashavet22@yahoo.com

Citation | Younis GA, Esawy AM, Elkenany RM, Shams El Deen MM (2020). Conventional identification of pathogenic fungi isolated from fresh water aquarium fish (O. niloticus and C. gariepinus) combined with molecular identification of Saprolegnia parasitica in egypt. Adv. Anim. Vet. Sci. 8(1): 77-88.

DOI | http://dx.doi.org/10.17582/journal.aavs/2020/8.1.77.88

ISSN (Online) | 2307-8316; ISSN (Print) | 2309-3331

Copyright (C) 2020 Younis et al. This is an open access article distributed under the Creative Commons Attribution License, which permits unrestricted use, distribution, and reproduction in any medium, provided the original work is properly cited.

\section{INTRODUCTION}

$\mathrm{F}$ resh water fish, Oreochromis niloticus (Nile tilapia) and Clarias gariepinus (African catfish), is one of the most important protein sources for people in a lot of countries (Iqbal et al., 2012). Aquacultures incorporated into the farming system have been revealed to develop food security with slight external inputs (Wetengere, 2010). However, mortality and sever economic losses amongst the ornamental and food fish farming industries as the chief features of fungal infections were exhibited (Ali, 2015). For example, epizootic ulcerative syndrome (EUS) infection was one of most common disease caused by Aspergillus niger and Aspergillus fumigatu in fresh water fish (Chauhan, 2013). Really, the incidence and diversity of fungi as well as their secondary metabolites in aquatic systems are occupied a worldwide growing interest. Nonetheless, such concern is hindered by the scarce data about aquatic fungi in the investigations (Magwaza et al., 2017). Many of the fungi affected fish are considered opportunists. Fish is attacked when it is immunocompromised or stressed owing to unfavorable environment or subsequent to bacterial in- 
fections (Refai et al., 2010). Lot of efforts to characterize fungi among fresh water fish were performed and could be a great approach to identify fungi that play a role in overall fish health (Tartor et al., 2017).

For instance, the fungal infections associated with a lot of clinical abnormalities represented in the form of skin darkening, emaciation, necrotic lesions with sloughing of body fins and tail with peticheal haemorrhage and cotton wool like growth on different parts of the skin with sloughing of the upper layers of skin (Mohamed et al., 2013). The postmortem lesions caused by pathogenic fungi, mainly $A$. favus were yellow liver as aresult of protease production (Essien et al., 2005), congestion in the internal organs as liver, enlargement in the spleen and nodules on the surface of the kidney (Hassan et al., 2010). The infected C. gariepinus with Cladosporium spp. and Alternaria spp. showed severe erosions and ulcerations of the skin in the posterior part of the body as well as black liver with congestion in internal organs (Tasic, 2007).

The phenotypical characteristics for instance; colony morphology, microscopic and biochemical examinations, have been the most common procedure for identification of fungi in clinical samples. However, this procedure is tedious, exorbitant and necessitates experienced microbiologists and an appropriate control in culture conditions that could involve in various outcomes and the findings might occasionally be indecisive, mostly for uncommon fungi (Agustini et al., 2014). The gene amplification and sequencing is the best method for identification of fungal species which are hard to identify by the phenotypic procedure, although such method is not commonly available and thus usually not portion of routine identification (Petti, 2007).

Oomycetes (water moulds) of the order Saprolegniales such as Saprolegnia spp., are incriminated in devastating infection (Saprolegniasis) of fish in aquaculture fish farms (Pieter, 2006). Saprolegniasis causes numerous damages in natural ecosystems and essential economic losses for the aquaculture industries. The presence of such disease is correlated to seed stage, mechanical injury, stress, immunocompromise, diminishes water quality, poor hygiene and crowdness (Osman et al., 2010; Karouei et al., 2012). The growing sign of the infection is characteristically established as a relativity superficial, cotton-wool like, white growth of mycelia on the fish skin especially around the head, dorsal and caudal fins, gills, in muscular layer and internal organs (Chauhan et al., 2014). Saprolegnia spp. were conventionally recognized depending on their reproductive structure morphology (Die'guez-Uribeondo et al., 2007). Lately, molecular approaches as polymerase chain reaction (PCR) joined with partial sequencing of ITS gene are the best recent methods to differentiate $S$. parasitica from other Saprolegnia spp. (Ke et al., 2009).
Thus, the present study aimed to identify aquatic fungi affecting diseased fresh water fish through using fungal morphological parameters, experimental challenge of the representatives of the identified fungal isolates and polymerase chain reaction amplification of Internal Transcribed Spacer (ITS1-ITS4) regions of ribosomal DNA as the reference method for Saprolegnia parasitica identification, in Egypt.

\section{MATERIALS AND METHODS}

\section{Sampling and Clinical Examination}

A total of 500 apparently healthy and diseased freshwater fishes including 300 Nile tilapia (Oreochromis niloticus) and 200 Nile catfish (Clarias gariepinus) were obtained randomly from different fish farms located in Menzalah and El-Mansoura cities, Dakahlia province, Egypt, throughout the period from January to December 2017. Fishes were conveyed instantly alive or freshly dead to the lab. They were exposed to clinical and postmortem inspections for the existence of any lesions concerning skin/fins, gills, eyes and internal organs (liver, kidney, and spleen) as observed by Lucky (1977) and Austin and Austin (2012) and displayed in Figures (1-6).

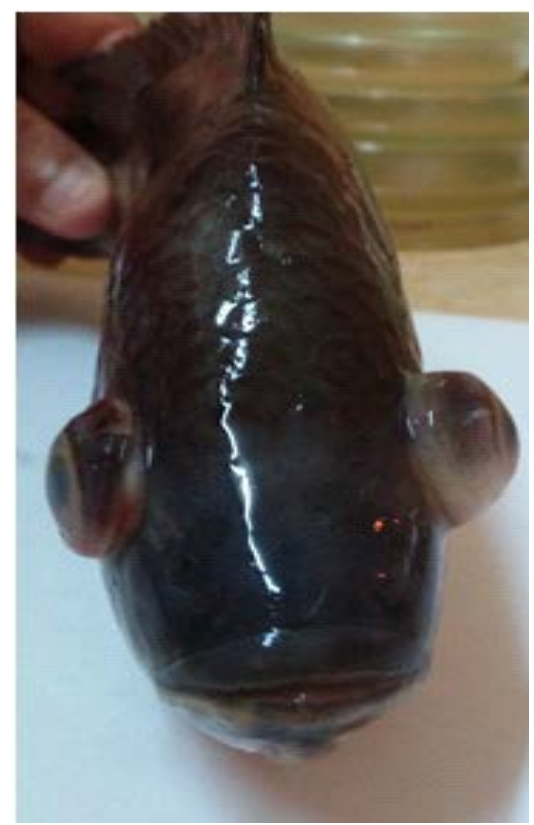

Figure 1: Oreochromis niloticus with severe bilateral hemorrhagic exophthalmia.

\section{Mycological Analysis}

A total of 6 samples (skin/fins, gills, eyes, and internal organs; liver, kidney, and spleen) from each fish species were taken for mycological analysis. Each sample was inoculated onto Sabouraud's dextrose agar with chloramphenicol (SCG Laboratorios CONDA, S.A. Cat.No.1090) (Eissa et al., 2013; Raggi et al., 2014). Then, they were incubated at $28 \pm 2{ }^{\circ} \mathrm{C}$ for $3-10$ days. Fungal isolates were identified according to cultural characteristic, morphology of hyphae 
cells, spores and kind of fruiting bodies (Koeypudas et al., 2005) after staining by lactophenol cotton blue (LPCB). All yeast isolates were subsequently cultivated on Rice agar plate and observed microscopically for the existence of blastospores, hyphae, pseudohyphae, chlamydospores and arthrospores (Hazen, 2007). Several biochemical identification tests were used to diagnose yeast isolates such as sugar fermentation and assimilation tests.

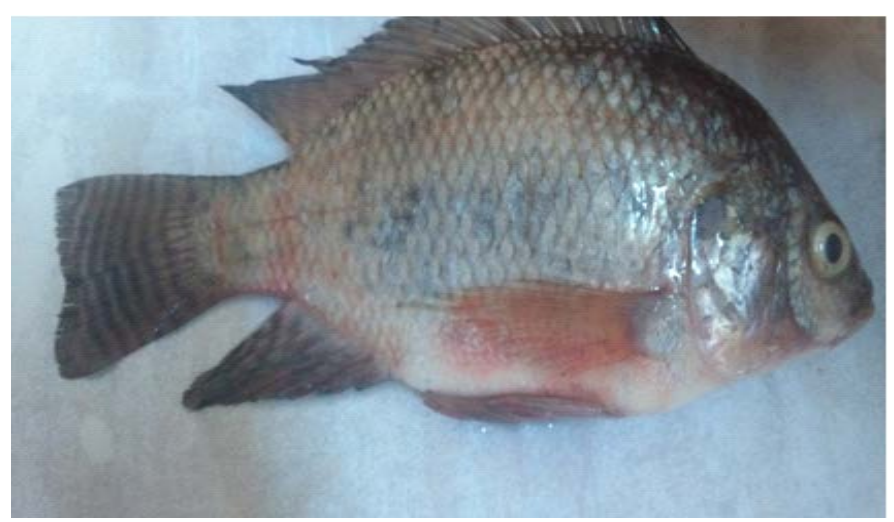

Figure 2: Oreochromis niloticus with congested caudal peduncle area.

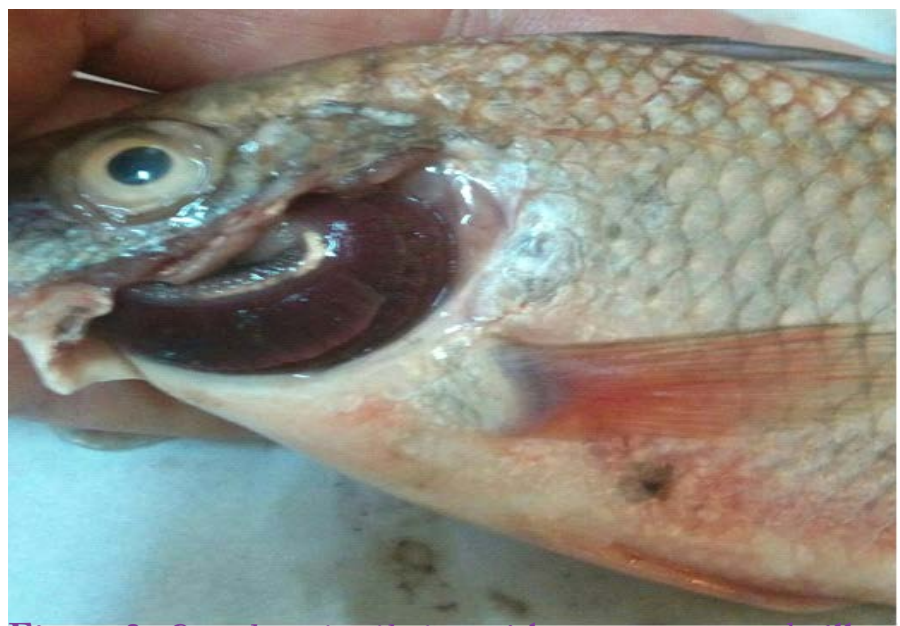

Figure 3: Oreochromis niloticus with sever congested gills.

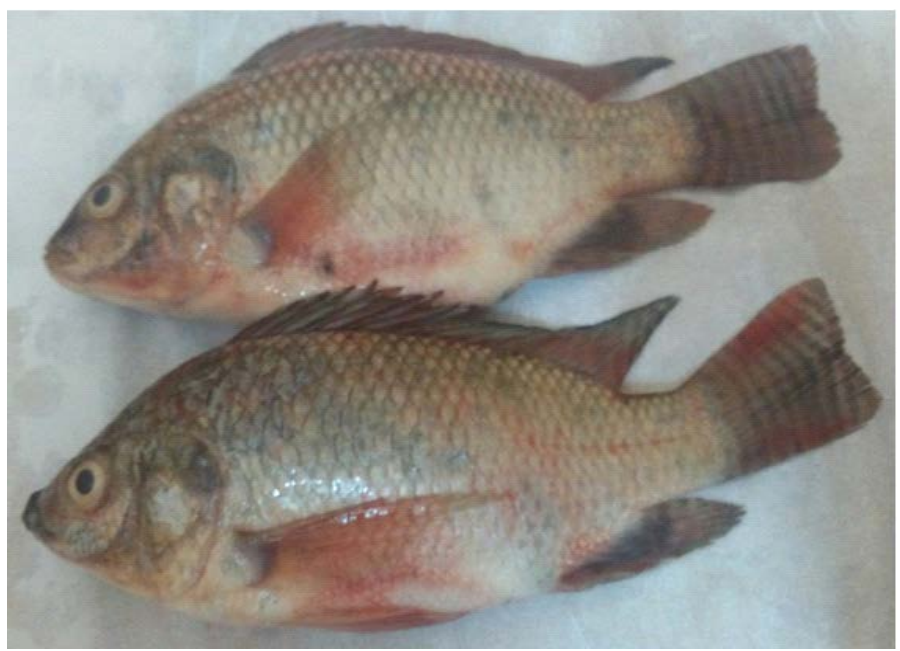

Figure 4: Oreochromis niloticus with congested, sloughed tail fin and ascitis.

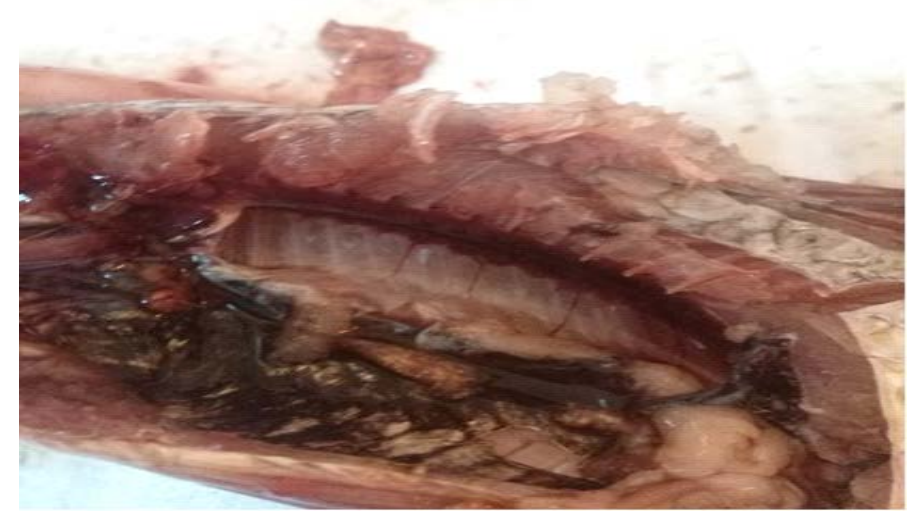

Figure 5: Oreochromis niloticus with sever congested kidneys.

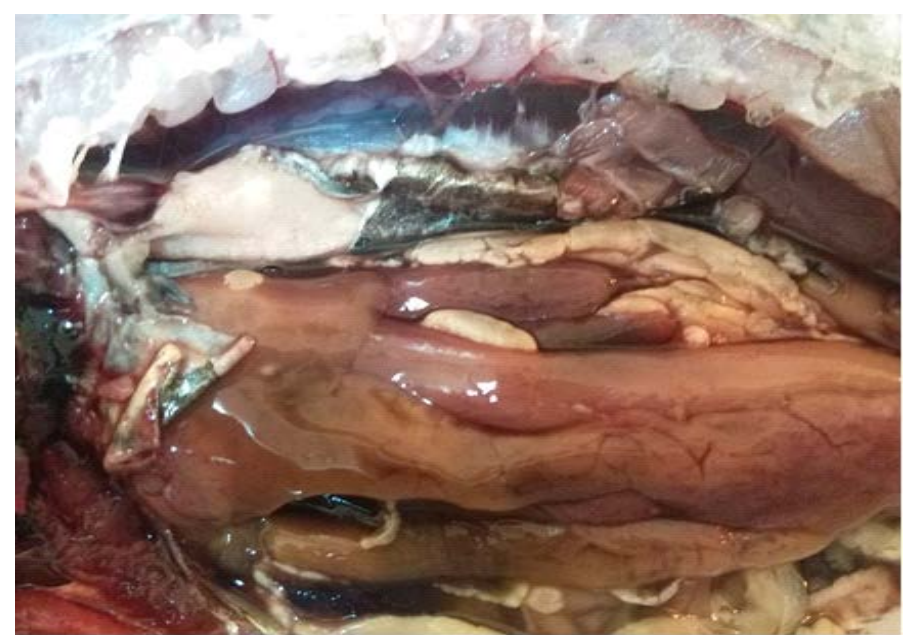

Figure 6: Oreochromis niloticus with threads of congestion along the surface of liver.

\section{Experimental Chellanges}

Seven representatives of the identified fungi comprising genus Aspergillus (A. flavus, A. niger, A. fumigatus), Penicillium, Saprolegnia, Cladosporium and Candida were utilized for experimental challenging of C. gariepinus (Table 1). In total, 160 C. gariepinus with average weight $250 \pm 10 \mathrm{~g}$ were separated into eight groups ( $\mathrm{n}=20 \mathrm{fish} /$ group), each group was divided into two subgroups $(\mathrm{n}=10)$ and distributed in two glass aquaria $(30 \times 50 \times 100 \mathrm{~cm})$ at a density of $10-$ fish per aquarium. Fishes were adapted for 2 weeks, nourished on artificial diet, provided with dechlorinated water that was constantly ventilated and the temperature kept at $20 \pm 2{ }^{\circ} \mathrm{C}$. Following two weeks, each subgroup of the fish were inoculated intraperitoneum $(\mathrm{I} / \mathrm{P})$ or intramuscu$\operatorname{lar}(\mathrm{I} / \mathrm{M})$ with $1 \mathrm{ml}$ of spore suspension $\left(9 \times 10^{4}\right.$ spores $\left./ \mathrm{ml}\right)$ or yeast suspension containing $2 \times 10^{3} \mathrm{CFU} / \mathrm{ml}$ which was confirmed by haemocytometer counting chamber beforehand challenging (Olufemi et al., 1983; Refai et al., 2010). Control group was inoculated with $1 \mathrm{ml}$ of sterilized physiological saline. For one week, the observed clinical signs and mortalities of experimentally challenged fish were 


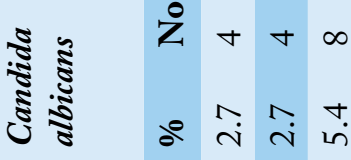

Z

赵

艺

己

폰

๙ูป

焉

过

है

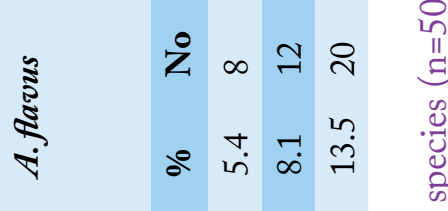

ป

ग

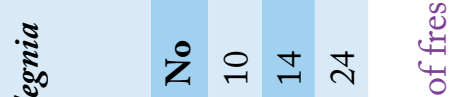

离

के

I

告

之 $\stackrel{\infty}{+}$

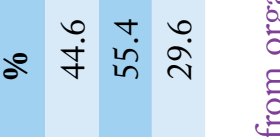

Z

\&

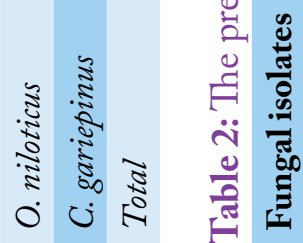

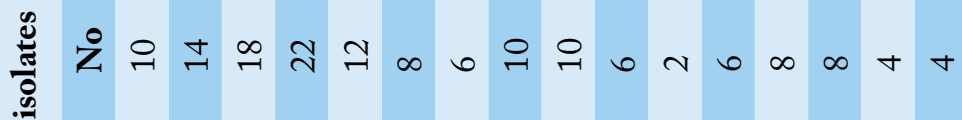

$$
\begin{aligned}
& \text { • } \\
& \text { Z }
\end{aligned}
$$

离

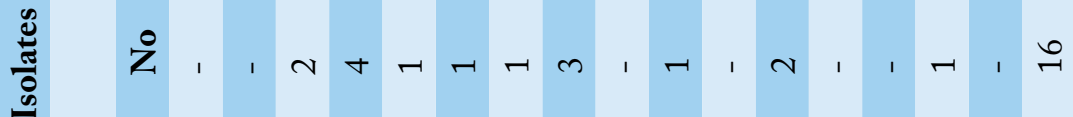

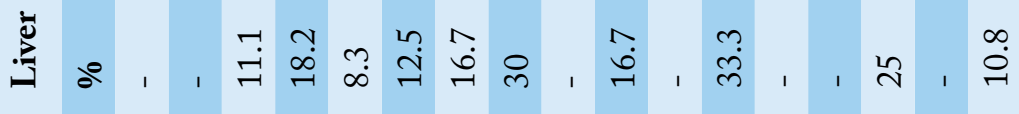
$\stackrel{0}{z}+c$

离

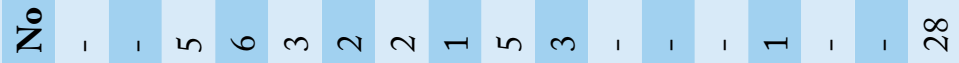

产

g

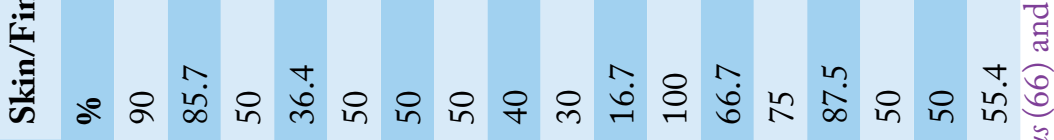

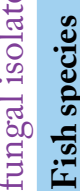
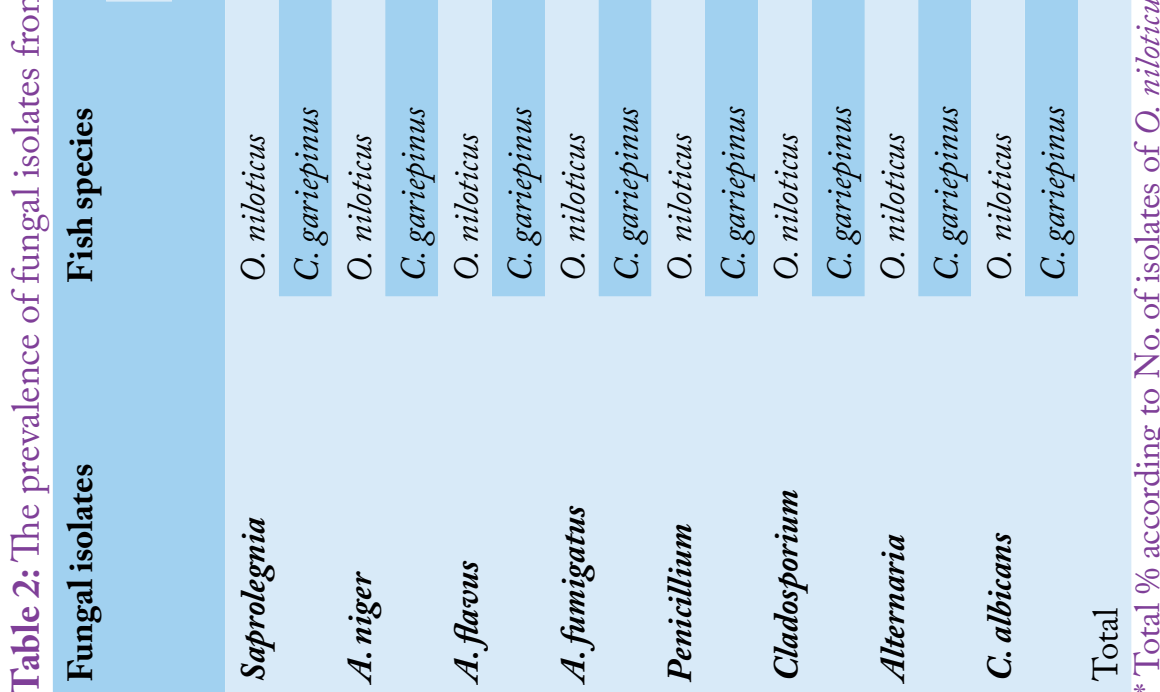
OPEN ○ACCESS

stated and also fungal isolation and identification were performed from fresh dead fish.

\section{Molecular Identification of Saprolegnia} PARASITICA

Genomic DNA from nine representative isolates of Saprolegnia parasitica was extracted according to Jara et al. (2008) for detection of ITS gene by polymerase chain reaction. Amplification of DNA was applied using the primer set ITS1 (5'-TCCGTAGGTGAACCTGCGG-3') and ITS4 (5' TCCTCCGCTTATTGATATGC-3'), subsequent the protocol stated by Ke et al. (2009). The reaction profile included one initial cycle at $94{ }^{\circ} \mathrm{C}$ for $5 \mathrm{~min}$; followed by 35 cycles of amplification comprising a denaturation step at $94^{\circ} \mathrm{C}$ for $30 \mathrm{~s}$; annealing at $58^{\circ} \mathrm{C}$ for $30 \mathrm{~s}$, extension at $72^{\circ} \mathrm{C}$ for $1 \mathrm{~min}$ and final extension at $72^{\circ} \mathrm{C}$ for 5 minutes. Polymerase chain reaction fragment lengths were detected using 1.2\% agarose gel electrophoresis and image photographed by a gel documentation system (Alpha Innotech, Biometra).

\section{RESULTS}

\section{Prevalence of Fungi Isolated from Fish}

The prevalence of different fungi among 500 samples from O. niloticus and C. gariepinus was 148 (29.6\%) with 6 genera: Aspergillus spp. (A. flavus, A. niger, A. fumigatus), Penicillium spp., Saprolegnia, Cladosporium spp., Alternaria spp. and Candida spp. identified (Table 1) (Figure 7-14). Of the infected fishes, C. gariepinus displayed the higher number of fungal isolates $(\mathrm{n}=82 ; 55.4 \%)$ than O. niloticus $(\mathrm{n}=66$; 44.6\%). The most prevalent fungi was Aspergillus spp. (76/148; 51.3\%) with $A$. niger as the predominant species (40/148; 27\%), Saprolegnia spp (24/148; 16.2\%), Penicillum spp., Alternaria spp. (16/148; 10.8\% each), Cladosporium spp. and C. albicans (8/148; 5.4\%). Frequency distribution of fungi isolated from organs and tissues of fish species showed high occurrence of fungi in skin/fins (55.4\%), subsequently gills (18.9\%) and internal organs (liver 10.8\%, kidney $10.2 \%$, eyes $2.7 \%$ and spleen $2 \%$ ) as depicted in Table (2). Interestingly, considering localities, a high prevalence of fungi from Menzalah fish farms (130/360; 36\%) with $A$. niger $(34 / 360 ; 26 \%)$ as the predominant species was recognized, while a low rate of fungal infection was detected in El-Mansoura fish farms $(18 / 140 ; 13 \%)$ with A. niger $(6 / 140 ; 33.3 \%)$ as the most prevalent species (Table 3). The fungal infections varied according to seasons of the year (Table 4). The highest fungal infection rate was demonstrated during autumn (40/96; 41.7\%), followed by winter season $(62 / 172 ; 36 \%)$, summer season $(24 / 106$; $22.6 \%)$ and spring season (22/126; 17.5\%). All Penicillium spp. and Aspergillus spp. were isolated all over the year except $A$. fumigatus absent during spring season. Saprolegnia spp. was detected during winter and autumn seasons, while
Cladosporium spp.and Alternaria spp. were only determined during winter. C. albicans was identified during summer and autumn.

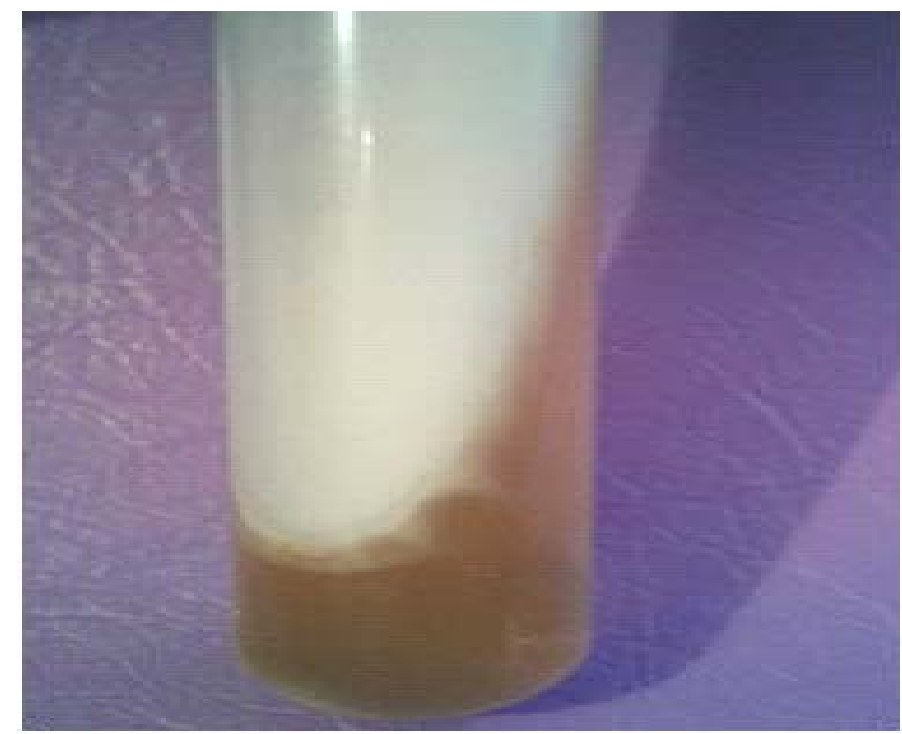

Figure 7: Saprolegnia spp.

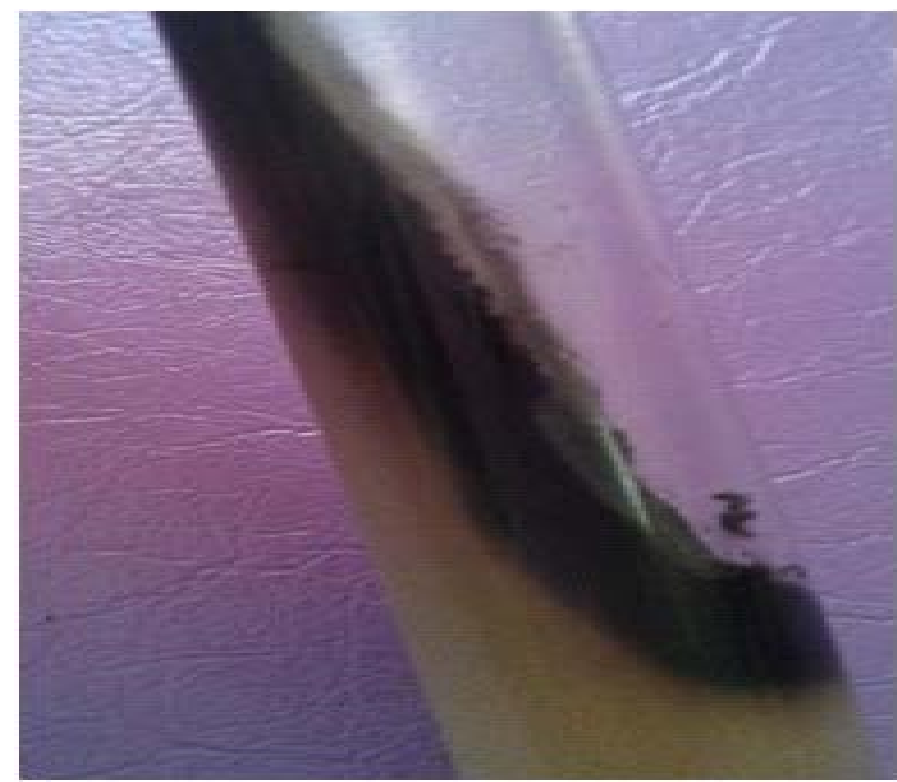

Figure 8: Aspergillus niger

\section{Effects of Experimental Challenge}

The intraperitoneum challenged fish groups with $A$. $f a^{-}$ vus, $C$. albicans, $A$. niger, Cladosporium spp. displayed the highest cumulative mortality percent $(100,80,70$ and $70 \%$ respectively), while Saprolegnia spp., Penicillium spp. and A. fumigatus demonstrated a lower mortality rate $(50,50$, $30 \%$ respectively) as illustrated in Table (5). The intramuscular challenged fish groups with $A$. flavus, A. niger and C. albicans revealed the highest mortality rate (60,50 and $50 \%$ respectively), whereas the lowest mortality rate was presented by Saprolegnia spp., Cladosporium spp., Penicillium spp. (40\% each) and A. fumigatus (20\%) (Table 5). Mortalities initiated within $24 \mathrm{~h}$ post infection. The major of challenged fish revealed similar clinical signs involving 


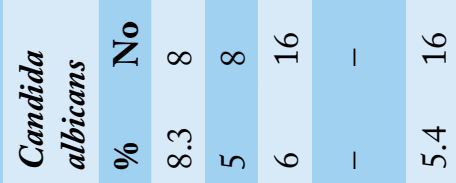

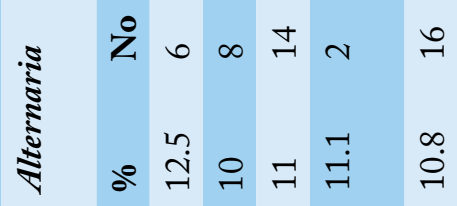

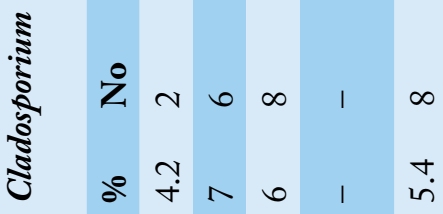

อ

苞

से

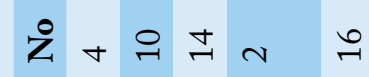

๓

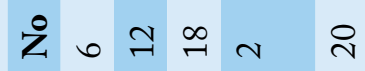

造

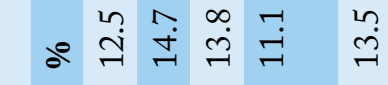

ఏँ

ब

ป⿱艹

है

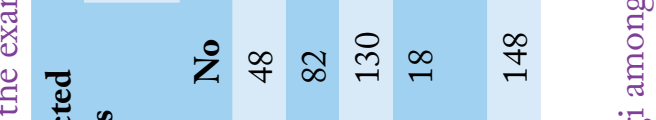

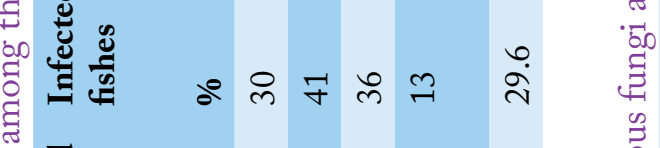

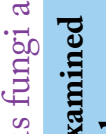

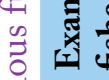

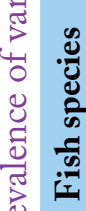

유 유요 윰

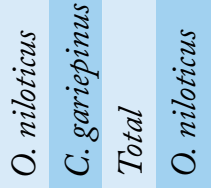

戸

ले

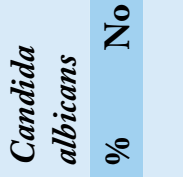

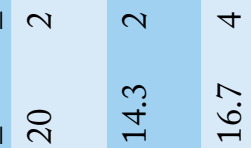

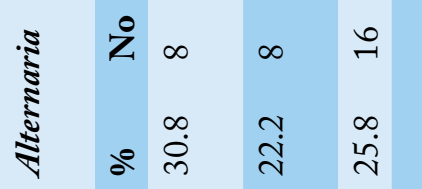

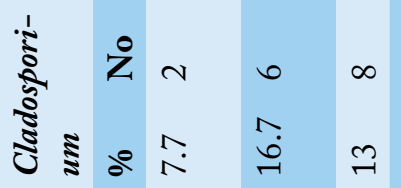

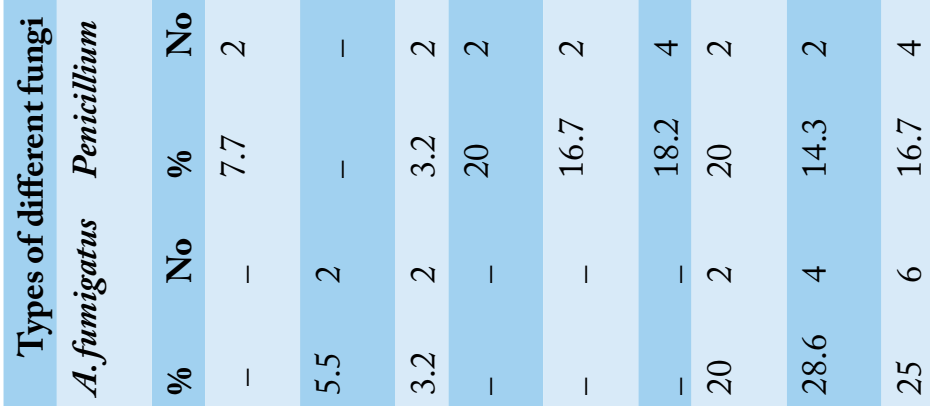

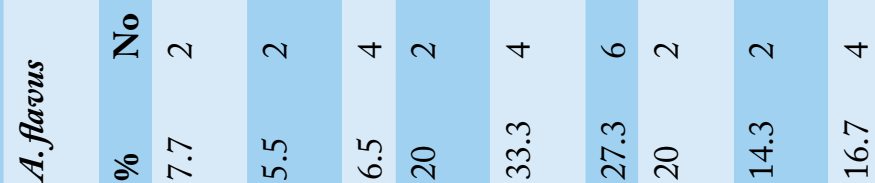

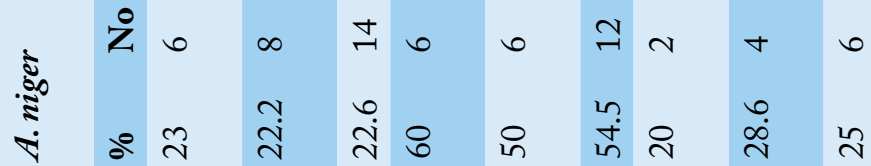

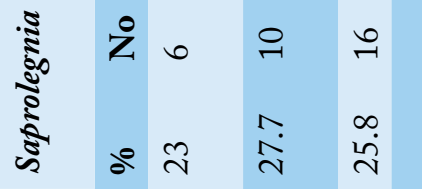

荧

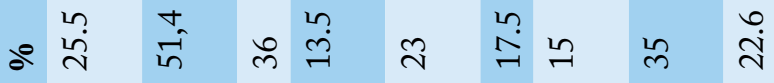
そ்

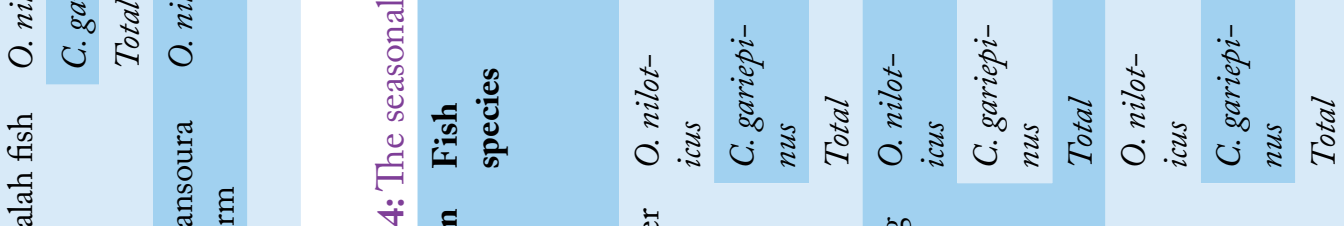




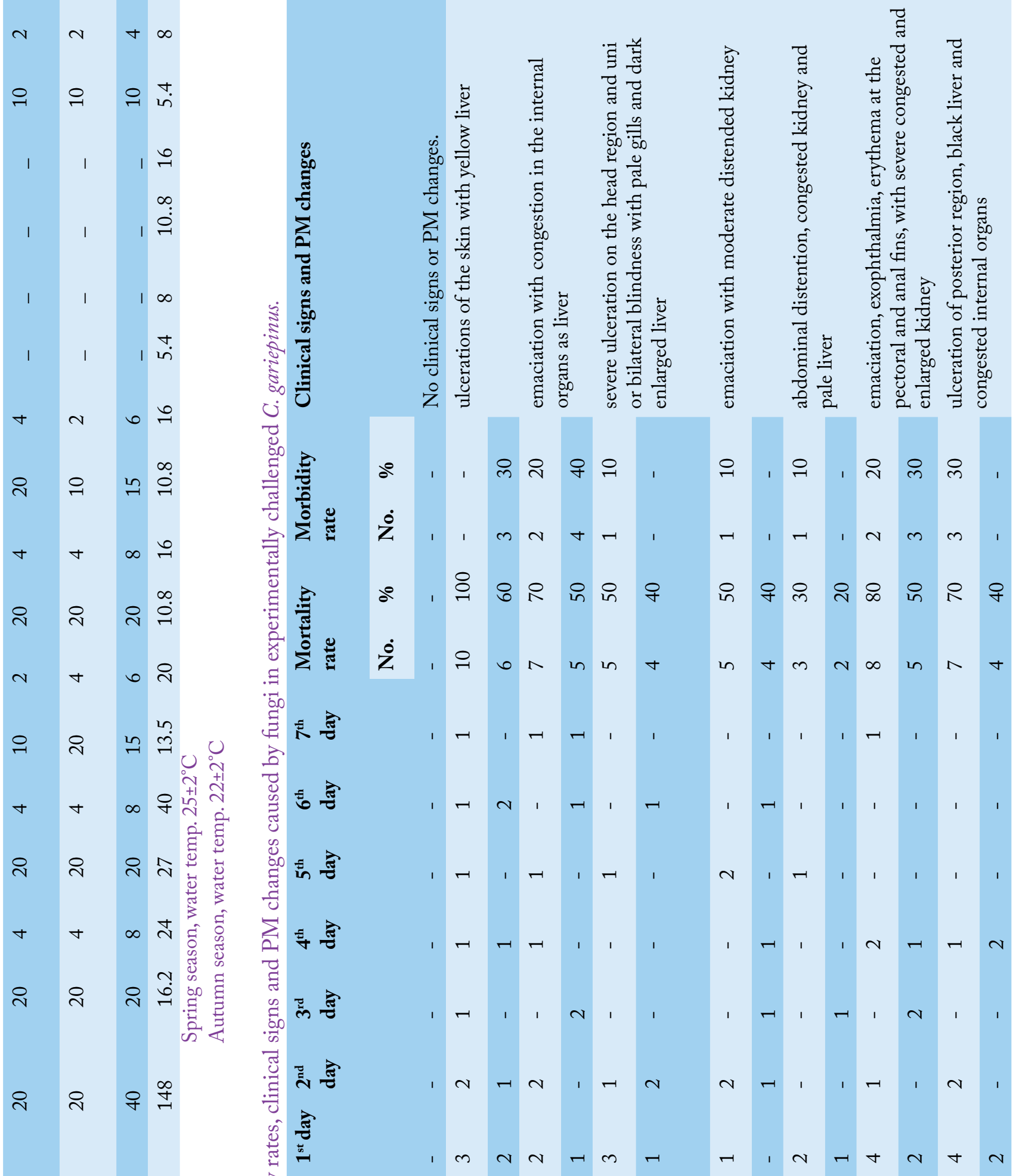

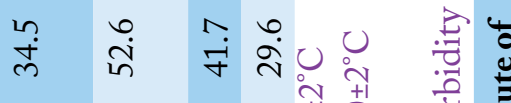

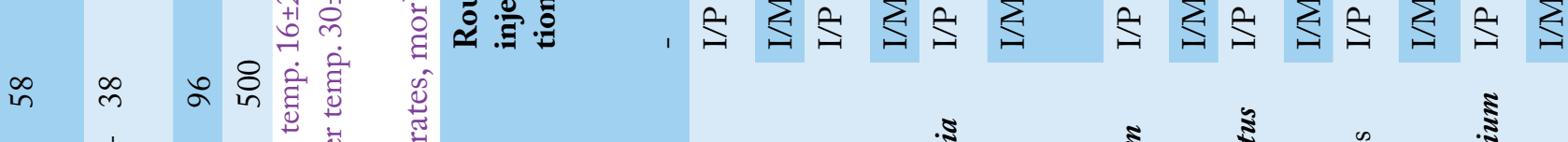

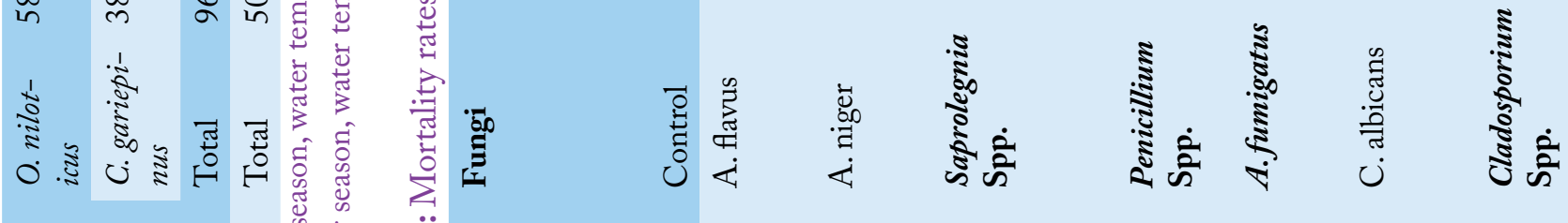

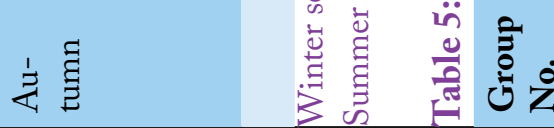




\section{OPEN OACCESS}

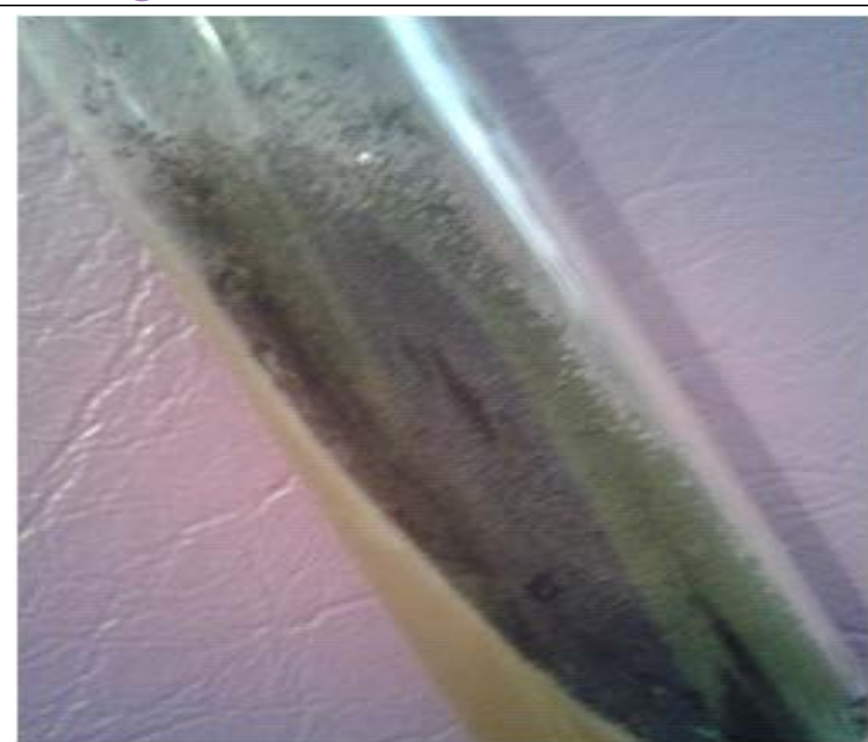

Figure 9: Aspergillus flavus

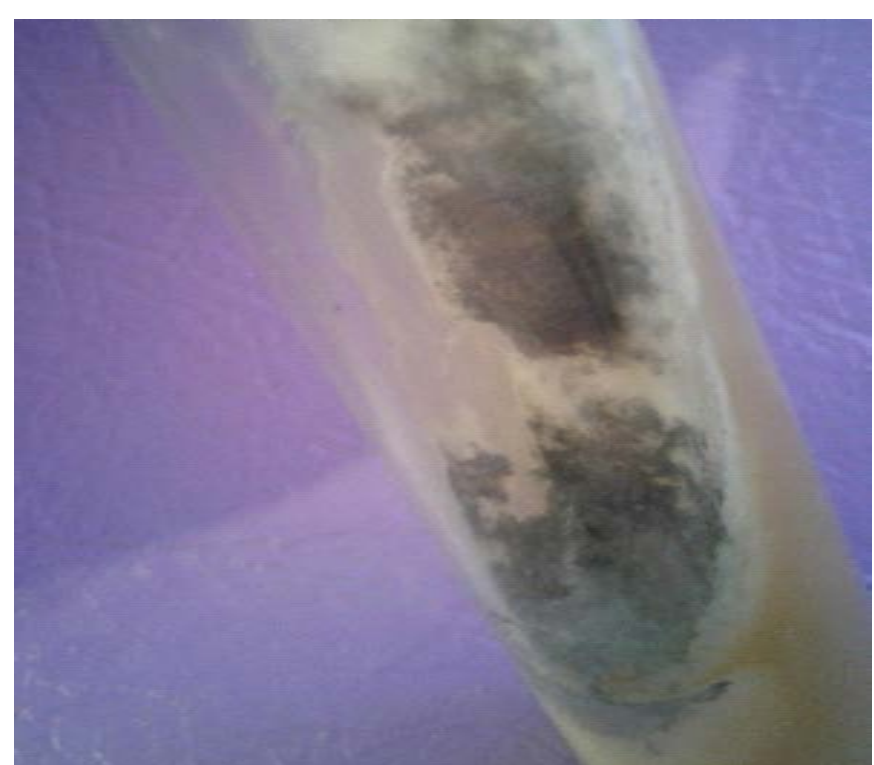

Figure 10: Aspergillus fumigatus

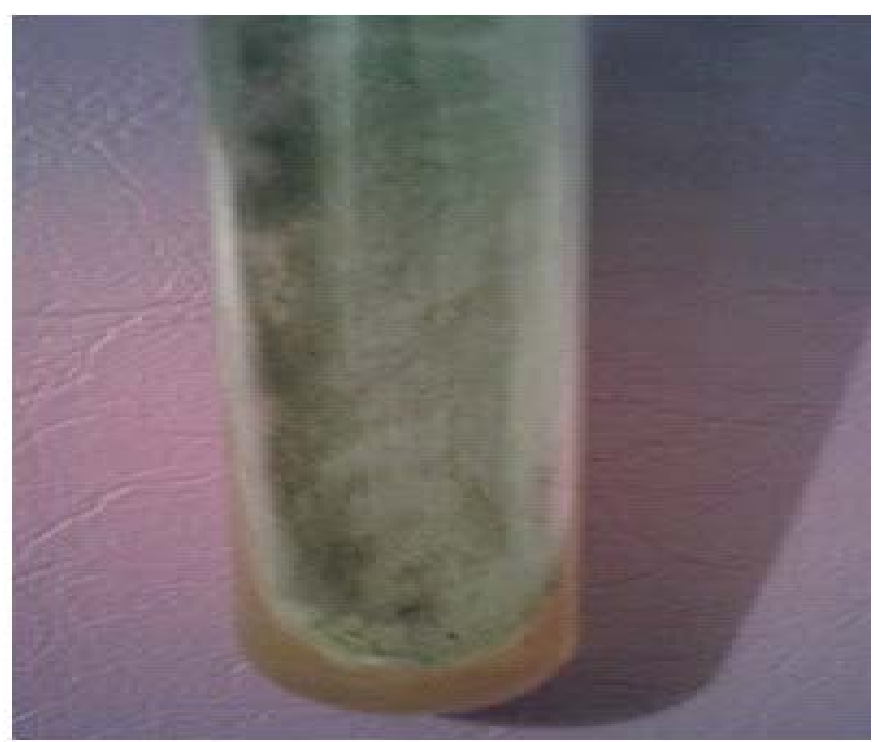

Figure 11: Penicillium spp.
Advances in Animal and Veterinary Sciences

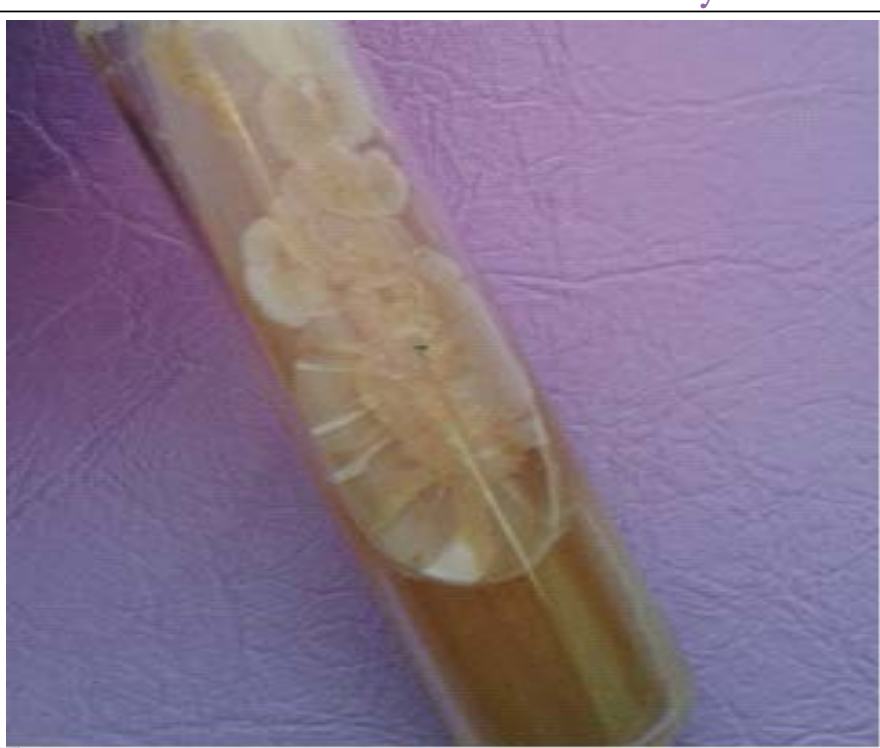

Figure 12: Cladosporium spp.

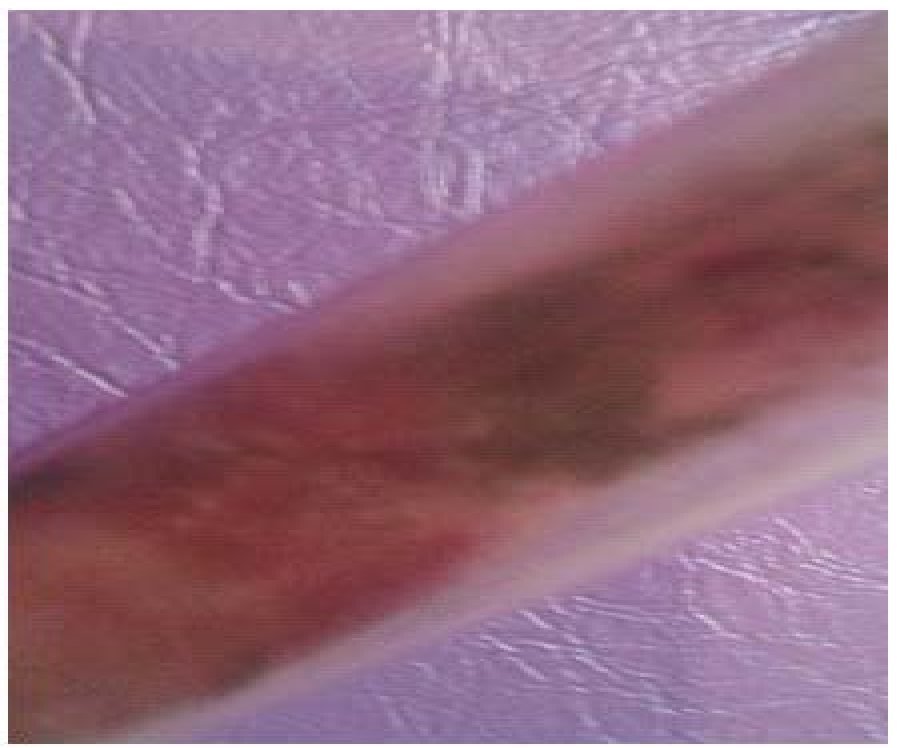

Figure 13: Alternaria spp.

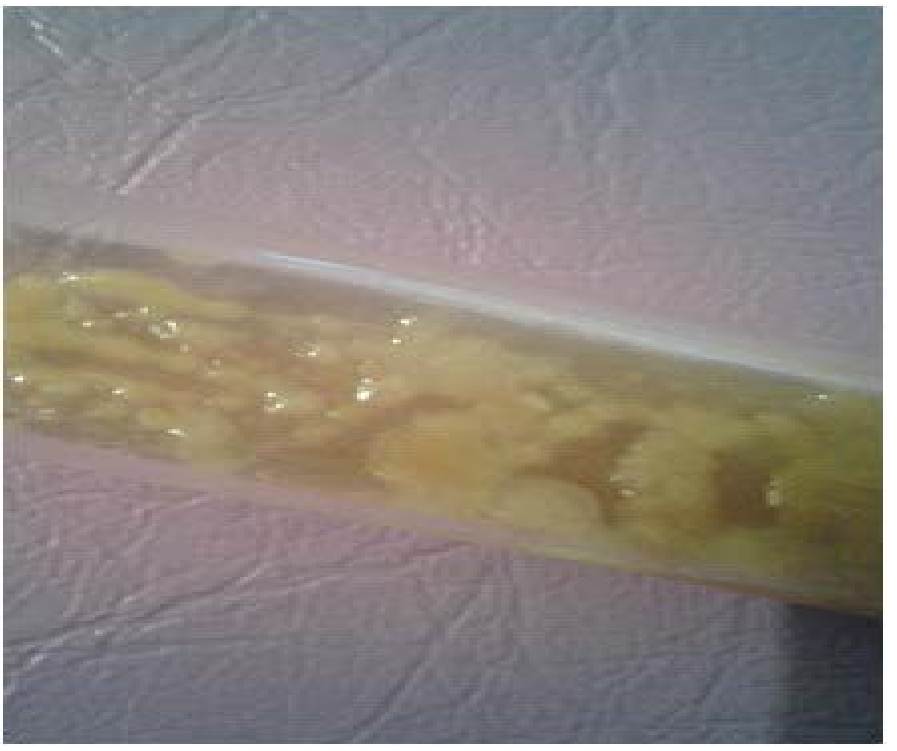

Figure 14: Candida Albicans 
severe emaciation, off food, aggregate near the aquarium sides, gasping air from water surface and loss of escape reflex. The postmortem examination showed severe congestion in the internal organs, prominently the kidney, liver and intestine and abdominal distention. No mortality or any behavioural changes was detected in the control group during the period of experiment. Reisolation and identification of fungi from dead experimentally inoculated fishes revealed that, it corresponded to the same tested strain of fungi used for challenge.

\section{Molecular IdentificAtion of SAProlegnia} PARASITICA

The PCR assay as a confirmatory test identified nine Saprolegnia parasitica strains $(9 / 9,100 \%)$ obtained from diseased fish by the primer pairs ITS1- ITS4 (Figure 15). The amplified product size was $300 \mathrm{bp}$.

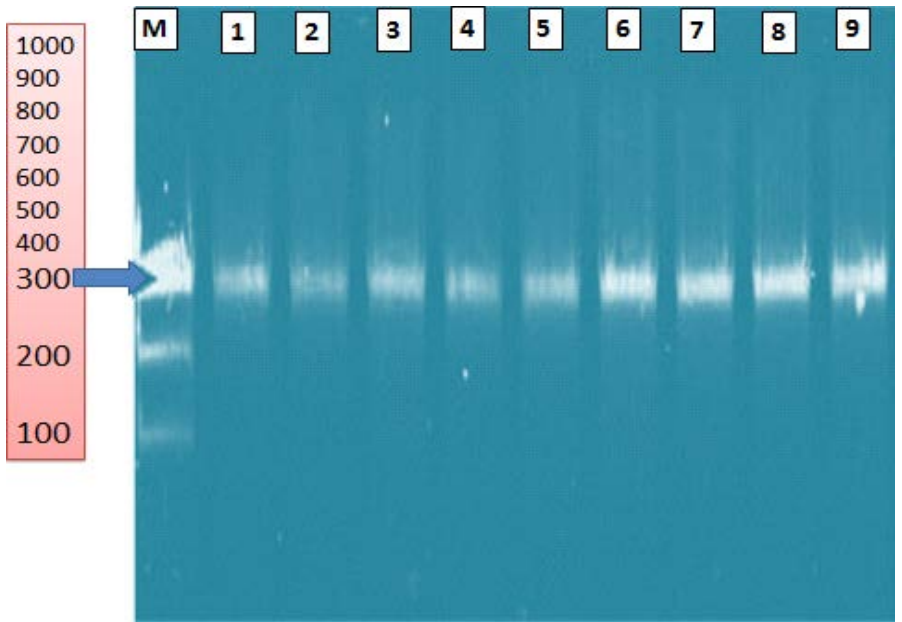

Figure 15: Agarose gel electrophoresis of Saprolegnia parasitica isolated from diseased fish showing ITS gene (300 bp). (M) ladder 100bp; lanes (1-9): positive samples

\section{DISCUSSION}

The fungal diseases constitute one of the most important diseases causing several economic losses in fresh and cultured fish worldwide, particularly Egypt. In this accordance, the aim of this investigation was to study fungi in two economically vital diseased freshwater fish species. A notable point in this work was that the diseased freshwater fish species had potential clinically applicable fungi in percentage 29.6\% including Aspergillus spp. (A. Alavus, A. niger, $A$. fumigatus), Penicillium spp., Saprolegnia, Cladosporium spp., Alternaria spp. and Candida spp. (Abd El-Ghany, 1998; Shabana, 2002; Blaylok et al., 2011). This result is consistent with Ibrahim et al. (2016) who isolated 32\% of fungi from fish lesions in Khartoum state. Aspergillomycosis is principally a disease of Oreochromis sp. caused by Aspergillus spp. (Willoughby, 1994). Additionally, this work revealed the highest prevalence of mould infection with Aspergillus species especially Aspergillus niger among fresh water fish.
These results were in agreement with that obtained by Shaheen (1986), Abd El-Ghany (1998), Oni et al. (2012), Jimoh et al. (2014) and Mohamed et al. (2017).

Moreover, C. gariepinus had the highest percentage of infection then O. niloticus. The variation in the infection percentage according to different fish species might be due to the scale less body of C. gariepinus that act as physical barrier against external pathogens especially mycotic agents (Osman et al., 2010).

Concerning occurrence of fungi in different external and internal organs, the highest percentage of infection in the skin/fins in comparison to gills and internal organs in this work might be regarded to saprophytic nature of fungi on fish mucous (Shaheen 1986; Udomkusonsri et al., 2007). There were a lot of fungal diseases infected the external tissue and few fungal infections outbreak the internal organs of fish (Mastan et al., 2015). Correspondingly, Refai et al. (2010) obtained different fungal isolates from diseased and apparently healthy Oreochromis species such as Aspergillus spp., Saprolegnia spp., Penicillium spp. and C. albicans from skin, gills, liver and kidney. Abd El-Ghany (1998) isolated A. flavus from skin, liver and kidney of C. gariepinus. This study revealed that, prevalence of different fungi among the examined fishes was $29.6 \%$ with variation in the infections percentage in relation to different localities (Menzalah fish farm 36\% and Mansoura fish farm 13\%) (Ali et al., 2011). Furthermore, the fungal diseases were affected by a changing thermal regimen. Therefore, the current investigation demonstrated the highest fungal infection rate during autumn, followed by winter season, summer season and spring season. This result is consistent to Rezeaka (1991) and Claireaux et al. (1995) who recorded the highest percentage of infection during autumn season due to sudden changes in the temperature.

According to association of fungal species and season, A. niger and Penicillium spp. isolates were high in spring season (El-Abbassy, 2007; Ahmed et al., 2012). The occurrence of infection by Saprolegnia spp., Alternaria spp. and Cladosporium spp. was high in winter season as their proliferation required to maintenance of lower temperature. These findings were supported by Rezeaka (1991), Grinn-Gofron (2007) and Verma (2008). The incidence of infection by $C$. albicans was high in summer season because yeast infections strike more in the warmer months (Hennessey, 2010).

Approximately all fungi identified in such investigation could be considered as normal mycoflora. On the contrary, it did not indicate that such fungi could not induce disease. These fungi could slightly be categorized as opportunistic fungi, since numerous of them contain virulence factors, 
that allow them to make diseases, especially under favorable predisposing environments. This is confirmed by several clinical findings that had determined after experimental exposure of C. gariepinus to various fungal isolates in such work. C. gariepinus inoculated either I/P or I/M with A. Alavus, C. albicans, A. niger, Cladosporium spp showed high mortality rate. Similar observation was reported by Abd El-Ghany (1998), Tasic (2007) and Oda et al. (2016). Whilst, Saprolegnia spp., Penicillium spp. and A. fumigatus demonstrated low mortality rate. These results were consistent with Abd El-Ghany (1998) and Osman et al. (2010).

The fish fungal pathogen (Saprolegnia) concerning to heterokonts group, responsible for Saprolegniosis, taken significant consideration amongst all the fungal pathogens of fish. Saprolegnia is extensively delivered to aquatic habitation and is an economically essential member of the class Oomycetes (Magray et al., 2018). Up to the last years of twentieth century, mycologists mostly depended on culturing, morphology and physiology of a fungal community for the classification goals. On the other hand, accelerated developments in the sequencing technology from later two decades has assisted the characterization of microbes established on molecular characters. Hence, morphology depended identification was useful with other advanced molecular methods, PCR assay, for precisely identification of Saprolegnia parasitica from other water moulds in this work. Internal Transcribed Spacer (ITS) regions of the ribosomal DNA, ITS1 and ITS2, is the real barcode to distinguish members of Oomycota, Saprolegnia and is further effective for the identification of fungi containing inter and intraspecific variations (Schoch et al., 2012). Consequently, genetic sequential analysis of these regions has been approved to examine nine retrieved Saprolegnia isolates. This investigation showed that all phenotypically Saprolegnia parasitica strains were genotypically positive. The genetic study established on the ITS ribosomal DNA region further approved the taxonomic position of the nine Saprolegnia strains and proved their identification as $S$. parasitica that concurs with the same findings by Cao et al. (2012) and Eissa et al. (2013).

\section{CONCLUSION}

The fungal infections were highly prevalent among fresh water fish species (O. niloticus and C. gariepinus) during low temperature seasons in Egypt with predominance of $A$. $n i$ ger and Saprolegnia spp, but other four genera were also encountered. The experimental challenge of representatives of the identified fungi effectively imitated most important clinical signs of naturally infected fish illustrating that such isolates were clinically substantial and point attention to the possible role of fungi in affecting $C$. gariepinus. Also, traditional identification combined with ITS amplification could be used as the gold standard for the identification of S. parasitica strains from diseased fish species. Such data imposes planning and application of biosecurity programs in addition to the establishment of therapeutic strategy to control fungal infection among fresh water fish.

\section{ACKNOWLEDGEMENTS}

Department of Bacteriology, Mycology and Immunology, Faculty of Veterinary Medicine, Mansoura University, Egypt, supported this study.

\section{CONFLICT OF INTEREST}

The authors declared no potential conflicts of interest with respect to this article.

\section{AUTHORS CONTRIBUTION}

Gamal A. Younis designed the experiment and revised the manuscript. Abo El Kheir M. Esawy shared in the collection of samples and in carrying out the practical part. Rasha M. Elkenany shared in writing the paper and took the responsibility of correspondence to the journal. $\mathrm{Mu}-$ hammad M. Shams E1 Deen collected fish samples and carried out the practical part. All authors approved the final version of the manuscript for publication.

\section{REFERENCES}

-Abd El-Ghany NA (1998). Studies on the linkage of fungi with some fish diseases in fish farm, M. V. Sc. thesis. Department of Microbiology, Faculty of Vet. Medicine, Zagazig University.

-Agustini BC, Silva LP, Bloch C, Bonfim TMB, Da Silva GA (2014). Evaluation of MALDI-TOF mass spectrometry for identification of environmental yeasts and development of supplementary database. Appl. Microbiol. Biotechnol. 98: 5645-5654. https://doi.org/10.1007/s00253-014-5686-7

-Ahmed SH, Mohamed FA, Yousif RA, Abdelwahab SK, Salih RRM (2012). Isolation of fungal species from Oreochromis niloticus from two environments. Int. J. Biol. Pharm. Allied Sci. 1 (7): 927-932.

-Ali EH, Hashem M, Al-Salahy MB (2011). Pathogenicity and oxidative stress in Nile tilapia caused by Aphanomyces laevis and Phoma herbarum isolated from farmed fish. Dis. Aquat. Organ. 94: 17-28. https://doi.org/10.3354/dao02290

-Ali HH (2015). Isolation and identification of pathogenic fungi from carp fish in suliamania province. Global J. Biochem. Biotechnol. 4 (4): 356-363.

-Austin B, Austin DA (2012). Characteristics of the diseases. In: Austin B, Austin DA (eds) Bacterial fish pathogens: diseases of farmed and wild fish. Springer-Verlag, Heidelberg, pp. 15-46. https://doi.org/10.1007/978-94-007-4884-2

- Blaylock RB, Overstreet RM, Klich MA (2011). Mycoses in red snapper (Lutjanus campechanus) caused by twodeuteromycete 
fungi (Penicillium corylophilum and Cladosporium sphaerospermum). J. Hydrobiol. 460: 221-228. https://doi. org/10.1007/978-94-017-3284-0_20

- Cao H, Xia W, Zhang S, He S, Wei R, Lu L, Yang X (2012). Saprolegnia pathogen from Pengze Crucian Carp (Carassius auratus var. Pengze) eggs and its control with traditional Chinese herb. Israeli J. Aquacult. - Bamidgeh.64:1-7.

- Chauhan R (2013). Studies on conidial fungi isolated from some fresh water fishes. J. Adv. Life Sci. 6: 131-135.

- Chauhan R, Bhatt MH, Lone SA (2014). Pathogenic Effects of Three Species of Fungi (Aphanomyces laevis, Aspergillus niger and Saprolegnia parasitica) on Gold Fish (Carrasius auratus L.). Indo Global J. Pharmaceut. Sci. 4 (2): 41-46.

- Claireaux G, Webber DM, Kerr SR, Boutilier RG (1995). Physiology and behaviour of free-swimming Atlantic cod (Gadus-Morhua) facing fluctuating temperature conditions. J. Experimen. Biol. 198 (1): 49-60.

-Die'guez-Uribeondo J, Fregeneda-Grandes JM, Cerenius L, Pe'rez-Iniesta E, Aller-Gancedo JM, Telleria MT, Soderhall K, Martın MP (2007). Re-evaluation of the enigmatic species complex Saprolegnia diclina-S. parasitica based on morphological, physiological and molecular data. Fungal Genet. Biol. 44:585-601. https://doi.org/10.1016/j. fgb.2007.02.010

-Eissa AE, Tharwat NA,Zaki MM (2013). Field assessment of the mid winter mass kills of trophic fishes at Mariotteya stream, Egypt: Chemical and biological pollution synergistic model. Chemosphere. 90:1061-1068. https://doi.org/10.1016/j. chemosphere.2012.09.010

-El-Abbassy MT (2007). Mycological aspects of quail carcasses with atrial to improve their sanitary status. M. V. Sc. Thesis, Faculty of veterinary medicine, Zagazig University.

-Essien JP, Ekpo MA, Brooks AA (2005). Mycotoxigenic and proteolytic potential of moulds associated with smoked Shark fish (Chlamydoselachus anguincus). J. Appl. Sci. Environ. Manag. 9 (3): 53-57. https://doi.org/10.4314/ jasem.v9i3.17352

-Grinn-Gofron A (2007). Cladosporium spores in the air of szcecin. Acta Agrobotanica. (93): 747-758. https://doi. org/10.1016/j.atmosres.2009.02.014

- Hassan Z, Khan M, Khan A, Javedl I (2010). Pathological responses of white leghorn breeder hens kept on Ochratoxin A contaminated feed. Pak. Vet. J. 30 (2): 118-123.

-Hazen KC, SAH (2007). Candida, Cryptococcus, and other yeasts of medical importance.In P. R. Murray, E. J. Baron, J. H. Jorgensen, M. L. Landry \& M. A. Pfaller (ed.), Manual of Clin. Microbiol, vol. 9. (pp. 1762-1788). ASM Press, Washington, DC.

-Hennessey M (2010). Talking business, stop ignoring the fungus. Blue Moose Consulting Newsletter. 7(5).

-Ibrahim WH, Nimir AH, El-Sanousi SM, Shuaib YA (2016). Aerobic bacteria and fungi from skin lesions of fish in Khartoum state. J.Adv. Vet. Anim. Res. 3(4): 375-385. https://doi.org/10.5455/javar.2016.c176

-Iqbal Z, Sheikh U, Mughal R (2012). Fungal infections in some economically important freshwater fishes. Pakistan Vet. J. 32 (3): 422-426.

-Jara C, Mateo E, Guillamón JM, Torija MJ, Mas A (2008). Analysis of several methods for the extraction of high quality DNA from acetic acid bacteria in wine and vinegar for characterization by PCR-based methods. Int. J. Food Microbiol. 128 (2): 336-341. https://doi.org/10.1016/j. ijfoodmicro.2008.09.008
-Jimoh WA, Oladele-Bukola MO, Adebayo MD, Yusuff AA, Azeez FA, Salami OO (2014). Microbial flora of the gastrointestinal tract of Clarias gariepinus caught from river Dandaru Ibadan, Nigeria. SokotoJ. Vet. Sci. 12 (2): 19-24.

-Karouei HSM, Haji SM, Aziz GI (2012). Isolation of Saprolegnia and the Influence of Root Ethanolic Extract of Ruta graveolens on Saprolegnia. Spp Growth. International J. Biosci. Biochem. Bioinformat. 2 (1): 64-67. https://doi. org/10.7763/IJBBB.2012.V2.72

- Ke XL, Wang JG, GU ZM, Li M, Gong XN (2009). Morphological and molecular phylogenetic analysis of two Saprolegnia sp. (Oomycetes) isolated from silver crucian carp and zebra fish. Mycolog. Res. 113:637-644. https://doi. org/10.1016/j.mycres.2009.01.008

- Koeypudas WP,Phadee J, Trongpires T, Hatai K (2005). Influence of $\mathrm{pH}$, temperature and sodium chloride concentration on growth rate of Saprolegnia sp. J. Scient. Res. Chulalongkorn University,.30:123-130.

- Lucky Z (1977). Methods for the diagnosis of fish diseases. Edited by Hoffman, G. L. Translated from Czechoslovakian.

- Magray AR, Lone SA, Ganai BA, Ahmad F, Dar GJ, Dar JS, Rehman S (2018). Comprehensive, classical and molecular characterization methods of Saprolegnia (Oomycota; Stramnipila), an important fungal pathogen of fish. Fungal Biol. Rev. https://doi.org/10.1016/j.fbr.2018.12.001

- Magwaza NM, Nxumalo EN, Mamba BB, Msagati TAM (2017). The occurrence and diversity of waterborne fungi in African aquatic systems: Their Impact on water quality and human health. Int. J. Environ. Res. Pub. Health. 14: 546. https://doi.org/10.3390/ijerph14050546

- Mastan SA, Begum SA, Ahmed MO, Shamshad S (2015). Mycotic infection in some economically important freshwater fishes.World J. Pharm. Pharmaceut. Sci. 4 (11): 1449-1456.

- Mohamed HMA, Emeish WFA, Braeuning A, Hammad S (2017). Detection of aflatoxin-producing fungi isolated from nile tilapia and fish feed. EXCLI J. 16:1308-1318.

-Mohamed IM, Abd Al-Azeem MW, Mahmoud MM, Abd-EL Aal AMM (2013). Microbiology studies on the affections of skin in sharp tooth catfish (Clarias Gariepinus). Assiut Vet. Med. J. 59 (137): 157-165.

- Oda SS, Tohamy HG, Massoud RG (2016). Pathological Alterations in Nile Tilapia Experimentally Infected with Streptococcus iniae and Candida albicans. Turkish J. Fisheries Aquat. Sci. 16: 779-788. https://doi.org/10.4194/13032712-v16_4_04

- Olufemi BE, Agius C, Roberts RJ (1983). Aspergillomycosis in intensively cultured Tilapia from Kenya. Vet. Rec. 12 (9): 203-204. https://doi.org/10.1136/vr.112.9.203

- Oni TA, Olaleye VF, Omafuvbe BO (2012). Preliminary studies on associated bacteria and fungal load of artificially cultured Clarias gariepinus (Burchell1822) fingerlings. Ife J. Sci. 15 (1): 9-16.

- Osman H, NoorEl Deen AE, Solman W, Aboud M (2010). Atrial for induction of Saprolegniosis in mugel cephalus with special reference to biological control. J. American Sci. 6 (6): 203-209.

-Petti CA (2007). Detection and identification of microorganisms by gene amplification and sequencing. Med. Microbiol. 44: 1108-1114. https://doi.org/10.1086/512818

- Pieter VW (2006). Saprolegnia parasitica, an oomycete pathogen with a fishy appetite: new challenges for an old problem. Mycologist. (3): 99-104. https://doi.org/10.1016/j. 
mycol.2006.06.004

- Raggi P, Lopez P, Diaz A, Carrasco D, Silva A, Velez A, Opazo R, Magne F, Navarrete PA (2014). Debaryomyces hansenii and Rhodotorula mucilaginosa comprised the yeast core gut microbiota of wild and reared carnivorous salmonids, croaker and yellowtail. Environ. Microbiol. 16: 2791-2803. https:// doi.org/10.1111/1462-2920.12397

- Refai MK, Mohamed LA, Kenawy AM, Shimaa ESMA (2010). The Assessment of Mycotic Settlement of Freshwater Fishes in Egypt. J. American Sci. 6 (11): 823-831.

- Rezeaka SS (1991). Integumentry mycosis in cultured fresh water fish and shrimps, M. V. Sc. Faculty of vet Med, Alex University.

-Schoch CL (2012). Nuclear ribosomal internal transcribed spacer (ITS) region as a universal DNA barcode marker for Fungi. PNAS. 109 (16): 6241-624. https://doi.org/10.1073/ pnas.1207508109

-Shabana YM (2002). The use of the host specific fungus, Alternaria eichhorniae, for biological control of water hyacinth. The Second Conference on Biological Control of Pests in Egypt. Inter. Center of Agriculture, Cairo, Egypt, pp: 180-212.

-Shaheen AAM (1986). Mycoflora of some freshwater fish. M.V.Sc. Thesis (Microbiology) Dept. of Micro, Faculty of vet. Med. Zagazig University.

- Tartor Y, Taha M, Mahboub H, El Ghamery M (2017). Yeast species associated with diseased fish: Occurrence, identification, experimental challenges and antifungal susceptibility testing. Aqua. https://doi.org/10.1016/j. aquaculture.2018.01.033

-Tasic S (2007). Cladosporium spp. cause of opportunistic mycoses. Acta Facultatis Med. Naissensis. 24 (1): 15-19.

-Udomkusonsri P, Trongvanichnam K, Limpoka M, Klanggkaew N, Kusucharit N (2007). In vitro efficacy of the antifungal activity of some Thai Medicinal-Plants on the pathogenic fungus, Saprolegnia parasitic H2, from fish. Kasetsart J. (Nature Science). $41: 56-61$.

-Verma V (2008). Fungus disease in fish, diagnosis and treatment, Review article. Vet. World. 1 (2): 62.

-Wetengere K (2010). The influence of technology characteristics on adaption of fish farming technology: case of selected villages in Morogoro Region, Tanzania. Asian J. Agric. Sci. (2): 69-7.

-Willoughby LG (1994). Fungi and fish diseases. Pisces press, Stirling, UK. Pp 57. 